Article

\title{
Spatiotemporal Analysis of Urban Growth Using GIS and Remote Sensing: A Case Study of the Colombo Metropolitan Area, Sri Lanka
}

\author{
Shyamantha Subasinghe *, Ronald C. Estoque and Yuji Murayama \\ Faculty of Life and Environmental Sciences, University of Tsukuba 1-1-1 Tennodai, Tsukuba City, \\ Ibaraki 305-8572, Japan; estoque.ronald.ga@u.tsukuba.ac.jp (R.C.E.); mura@geoenv.tsukuba.ac.jp (Y.M.) \\ * Correspondence: shyamtha@geoenv.tsukuba.ac.jp or subasinghepgia@gmail.com; Tel.: +81-029-853-4211 \\ Academic Editors: Qiming Zhou, Zhilin Li and Wolfgang Kainz \\ Received: 17 July 2016; Accepted: 22 October 2016; Published: 29 October 2016
}

\begin{abstract}
Understanding urban growth spatiotemporally is important for landscape and urban development planning. In this study, we examined the spatiotemporal pattern of urban growth of the Colombo Metropolitan Area (CMA)—Sri Lanka's only metropolitan area_from 1992 to 2014 using remote sensing data and GIS techniques. First, we classified three land-use/cover maps of the CMA (i.e., for 1992, 2001, and 2014) using Landsat data. Second, we examined the temporal pattern of urban land changes (ULCs; i.e., land changes from non-built-up to built-up) across two time intervals (1992-2001 and 2001-2014). Third, we examined the spatial pattern of ULCs along the gradients of various driver variables (e.g., distance to roads) and by using spatial metrics. Finally, we predicted the future urban growth of the CMA (2014-2050). Our results revealed that the CMA's built-up land has increased by 24,711 ha $(221 \%)$ over the past 22 years $(11,165$ ha in 1992 to 35,876 ha in 2014), at a rate of 1123 ha per year. The analysis revealed that ULC was more intense or faster during the 2000s (1268 ha per year) than in the 1990s (914 ha per year), coinciding with the trends of population and economic growth. The results also revealed that most of the ULCs in both time intervals occurred in close proximity to roads and schools, while also showing some indications of landscape fragmentation and infill urban development patterns. The ULC modeling revealed that by 2030 and 2050, the CMA's built-up land will increase to 42,500 ha and 56,000 ha, respectively. Most of these projected gains of built-up land will be along the transport corridors and in proximity to the growth nodes. These findings are important in the context of landscape and urban development planning for the CMA. Overall, this study provides valuable information on the landscape transformation of the CMA, also highlighting some important challenges facing its future sustainable urban development.
\end{abstract}

Keywords: Colombo Metropolitan Area; land-change intensity; gradient analysis; land-change modeling

\section{Introduction}

The demographic transformation of human societies into the urban era has pushed the monitoring of urban areas to the forefront of environmental and developmental agendas [1,2]. Due to this transformation, a higher percentage of the world's population currently resides in urban areas than ever before, and growth in urban areas is occurring at an unprecedented rate [3,4]. Since the late 20th century, this rapid urban growth has clearly moved from the Global North to the Global South [5]. Accordingly, many South Asian metropolitan areas have experienced dramatic urban growth, dominated by the continuous shrinking of rural areas into urban areas [6]. This trend has been characterized by massive congestion, poor public transportation, and a noticeable lack of proper sanitation in South Asian metropolitan areas. It has also increased socioeconomic disparities, crime, and vulnerability to natural 
and manmade risks [7]. In this context, an assessment of spatiotemporal patterns of land-use/cover changes and the factors affecting these transformations is vital to developing rational, economic, social, and environment policies [8].

During the past two decades, the Colombo Metropolitan Area (CMA), Sri Lanka's only metropolitan area and the country's "heartbeat" [9], located in South Asia, has experienced rapid urban growth. In 2013, the World Bank [9] indicated that Colombo city, the core of the CMA, was one of the fastest growing cities in South Asia. Since Sri Lanka's economy was opened up in the early 1980s, the prime urban area of the CMA has undergone various developmental stages [10]. Upon the conclusion of the 30-year civil war in 2009, the CMA began an era of rapid urban development that has led to higher population concentrations and more intense industrial activity [11]. Statistics show that in 2012, with 3.7 million inhabitants, the CMA accounted for more than $80 \%$ of the country's industrial output and about $50 \%$ of its gross domestic product (GDP) $[9,12,13]$.

The concentration of increased urbanization in the CMA has created environmental problems across the area that stem from extensive urban poverty, recurrent flooding, slum growth, extensive alteration of wetland ecosystems, and mismanagement of limited resources [14,15]. In addition, valuable urban green spaces have also been affected due to land-use/cover changes. In such a context, knowledge of the spatiotemporal pattern of urban growth is crucial in order to create sustainable urban development policies that can mitigate the adverse effects of urbanization and ensure sustainable urban development $[1,8,16]$.

The emergence of land-change science, including advances in GIS and remote sensing, has provided a platform to examine landscape transformations throughout space and time [1,17-20]. In urban environments, landscape transformations are mainly dominated by anthropogenic activities and are greatly influenced by the spatial expansion of built-up lands $[1,20,21]$. The techniques proposed by Aldwaik and Pontius [22] for analyzing the intensity of land change enable an understanding of the size and speed of land change across various time intervals. However, while characterizing the size and speed of land changes is important, it is also vital to examine the explanatory variables, or the factors driving such changes [23]. Such driving factors can help in the understanding of the spatiotemporal patterns of landscape transformations [20,24-27].

Gradient analysis, a commonly used concept in landscape ecology, can be used to characterize the spatiotemporal patterns of landscape transformations $[3,20,27]$. There is also an increased interest in the use of landscape or spatial metrics for characterizing the landscape structure and spatiotemporal pattern of landscape transformations $[1,4,20,28]$. These spatial metrics are developed based on information theory measures and fractal geometry $[29,30]$. The ability to quantitatively describe the landscape structure is a prerequisite for studying landscape functions and transformations, and spatial metrics have enabled the quantification of the three basic concepts used to describe the spatial structure of landscapes: fragmentation, connectivity, and diversity [31]. Various studies have successfully applied spatial metrics to characterize urban spatial structures and the spatiotemporal pattern of changes in urban landscapes $[1,4,20,28,32,33]$.

In addition, land-change modeling has also become an important technique for the exploratory analysis of potential future landscape transformations because knowledge of the trajectories of future landscape transformations is not only important for urban studies, but also for landscape and urban planning $[20,25,26,34]$. While several urban-related studies have been conducted in the CMA or in Colombo city [10-12,15], there is a lack of research that provides meaningful information on the dynamics of urban growth in the CMA. Hence, this study seeks to examine the spatiotemporal pattern of urban growth of the CMA across the 1990s and 2000s. Remote sensing data and GIS techniques, including land change intensity, gradient analysis, spatial metrics, and land-change modeling, were used to facilitate the analysis. 


\section{Materials and Methods}

\subsection{Study Area}

The CMA, situated in western Sri Lanka (Figure 1a,b), is the country's most important administrative, industrial, and commercial center. It enjoys urban primacy in the national urban system and serves as a node of the international urban system, being the country's only metropolitan area. Geographically, the area is located on a coastal plain with flat terrain and a fairly temperate climate.

Since ancient times, Colombo's port has dominated trading activities in South Asia because of its central location in the Indian Ocean. According to the available literature, more than 2000 years ago Colombo was known as a port city to Roman, Arabic, and Chinese traders [11]. By the mid-16th century, Portuguese invaders used Colombo's port as a trading post, and later, Dutch invaders in the 17th century and British invaders in the 19th century used Colombo's port as a military outpost [35]. In modern times, after the country gained independence from the British in 1948, the city began to grow slowly as the center of western Sri Lanka.

Currently, the CMA has a multi-ethnic, multi-cultural population. The Sinhalese, Muslim, and Tamil populations dominate, and there are also small groups of Chinese, Portuguese, Dutch, Malays, and Indians. In 1991, the CMA had a population of 3.39 million, which increased to 3.47 million and then to 3.70 million in 2001 and 2012, respectively [36-39]. Projections show that the CMA's population will increase to 5.1 million by 2035 [13]. The extent of the study area covers about 237,000 ha, encompassing the core of Colombo and its surrounding areas (Figure 1c).
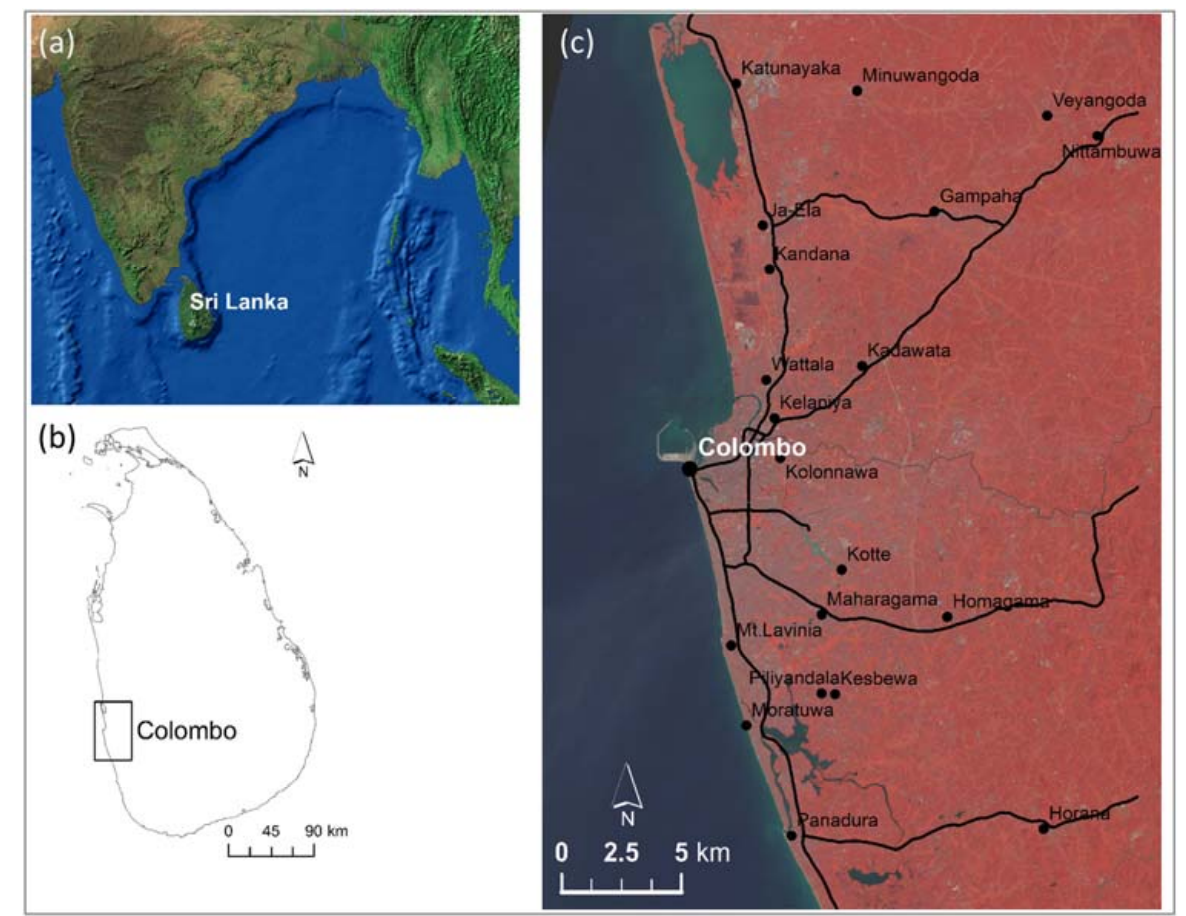

Figure 1. Location of the study area: (a) location of Sri Lanka in South Asia (Map Source: ArcGlobe data); (b) location of the CMA in Sri Lanka; and (c) the extent of the study area. Figure 1c shows the roads (lines) and growth nodes (points) in the CMA, overlaying a Landsat ETM+ (2014) displayed in a false color composite (RGB = Bands 5, 4,3).

\subsection{Land-Use/Cover Mapping}

Landsat images were used to map the land-use/cover of the CMA for three time points, i.e., 1992, 2001, and 2014. These images, with a spatial resolution of $30 \mathrm{~m}$, include a Landsat-5 TM image acquired on 13 January 1992; a Landsat-7 ETM+ image acquired on 27 December 2001; and a Landsat-8 
OLI/TIRS image acquired on 21 January 2014. For each time point, one scene (path 141, raw 55) was enough to cover the entire study area.

We used a pixel-based supervised classification technique employing the maximum-likelihood classification algorithm. This technique involved three main steps: training sites/sample preparation, signature development, and classification [20,40-42]. For the purpose of this study, we classified only three categories: built, non-built, and water. Built includes human-constructed structures such as buildings, roads, and other impervious surfaces. Non-built includes pervious surfaces such as agricultural lands, forests, grasslands, and bare lands. Water includes the sea, rivers, ponds, and other water bodies.

For the quantitative accuracy assessment of land-use/cover mapping, a total of 900 randomly selected sample points (300 per class) in shapefile format were used. Google Earth images and topographical maps (1:10,000 and 1:50,000, updated in 1990 and 2001) were used as reference in verifying the land-use/cover of these points. The accuracy of the classified land-use/cover map of 1992 was assessed using 1990 topographical maps. The 2001 classified land-use/cover map was assessed using Google Earth imagery and 2001 topographical maps (some parts are not clear on Google Earth), while the 2014 classified land-use/cover map was assessed using Google Earth imagery. The sample points verified using the topographical maps were first overlaid with the georeferenced topographical maps using ArcGIS software. The sample points verified using Google Earth images were first converted into $\mathrm{kml}$ file format and uploaded to Google Earth for a careful and rigorous visual inspection. The accuracy assessment results revealed that the classified land-use/cover maps had an overall accuracy of $88.66 \%$ (1992), 90.33\% (2001), and 92.66\% (2014) (see Appendix A for more details).

\subsection{Land Change Intensity Analysis}

Land-change intensity analysis $[1,22]$ was used to examine the extent and rate of urban land change in the CMA (ULC; i.e., a land change from non-built to built) across the two time intervals (i.e., 1992-2001 and 2001-2014). We first calculated the annual change intensity (ACI) for each time interval (1992-2001 and 2001-2014; Equation (1)). Then, we compared each ACI to the uniform intensity (UI), which is the rate of change relative to the entire time extent of the land-change analysis (Equation (2)) [1,22]. If the ACI in a particular time interval (e.g., t1-t2) is less than the UI, then the ACI intensity of that particular time interval is considered to be slow; but if it is greater than the UI, it is considered to be fast $[1,22]$.

$$
\mathrm{ACI}(\%)=\frac{(\mathrm{LC} / \mathrm{LA})}{\mathrm{TE}} \times 100
$$

where $\mathrm{ACI}$ is the annual change intensity for a given time interval (e.g., $\mathrm{t} 1-\mathrm{t} 2), \mathrm{LC}$ is the area of land change from non-built to built for a given time interval, LA is the area of the entire landscape, and TE is the duration of a given time interval.

$$
\mathrm{UI}(\%)=\frac{\left[\left(\mathrm{LC}_{\mathrm{TI} 1}+\mathrm{LC}_{\mathrm{TI} 2}\right)\right] / \mathrm{LA}}{\mathrm{TE}_{\mathrm{TI} 1}+\mathrm{TE}_{\mathrm{T} 2}} \times 100
$$

where $\mathrm{LC}_{\mathrm{TI} 1}$ and $\mathrm{LC}_{\mathrm{T} 2}$ are, respectively, the land change from non-built to built during time interval 1 and time interval 2. $\mathrm{TE}_{\mathrm{TI} 1}$ and $\mathrm{TE}_{\mathrm{TI} 2}$ are, respectively, the durations of time intervals 1 and 2.

\subsection{Gradient Analysis of ULCS}

We define "gradient" as the variation in the values of a given variable, e.g., distance to the growth nodes, across its range of values $[3,20,43]$. Based on our local knowledge of the study area, we identified four important factors that are potentially driving the spatial pattern of ULCs in the CMA. These are: the distance to major roads, distance to schools, distance to growth nodes, and distance to the administrative centers (Table 1). We first created a multiple ring buffer around each driver variable with a zone size of $300 \mathrm{~m}$. Then, we examined the extent of ULCs along the gradient of each variable across the two time intervals (1992-2001 and 2001-2014). 
Table 1. Driving factors and their descriptions.

\begin{tabular}{ll}
\hline Representative Factors & Descriptions \\
\hline Distance to major roads & $\begin{array}{l}\text { Represents access to transport facilities. The road map } \\
\text { (1995) includes only A and B types (major roads). }\end{array}$ \\
\hline Distance to schools & $\begin{array}{l}\text { Represents access to educational services. The map } \\
\text { shows the spatial distribution of primary and secondary } \\
\text { schools as of 2000. }\end{array}$ \\
\hline Distance to growth nodes & $\begin{array}{l}\text { Represents access to urban facilities and locations of } \\
\text { export processing zones (EPZ). Includes emerging urban } \\
\text { centers identified in 1996 by Sri Lanka's urban } \\
\text { development authority (UDA). }\end{array}$ \\
\hline Distance to administrative centers & $\begin{array}{l}\text { Represents access to administrative services. Includes } \\
\text { local and national government administrative-service } \\
\text { offices (1999). }\end{array}$ \\
\hline
\end{tabular}

\subsection{Spatial Metrics}

Although many pattern metrics have been used in various geospatial applications, there exists neither a standard definition of pattern metric nor a standardized process for their selection for particular applications [44,45]. Many spatial metrics also overlap [46]. In this study, the selection of metrics was based on similar previous works $[20,28,47]$. We used three landscape-level metrics and five class-level metrics to examine landscape fragmentation and connectivity. The landscape-level metrics included the contagion index (CONTAG), the landscape shape index (LSI), and Shannon's diversity index (SHDI). The class-level metrics included the percentage of landscape (PLAND), path density (PD), mean patch size (Area_MN), area-weighted mean patch fractal dimension (Frac_AM), and mean Euclidean nearest neighbor distance (ENN_MN). All these metrics were calculated using the FRAGSTATS 4.1 software, employing the 8-cell neighbor rule. Details of these metrics can be found in McGarigal et al. [48].

\subsection{Urban Land Change Modeling}

Here, we used the multi-layer perceptron neural network (MLP NN) and CA-Markov modules available in the TerrSet GIS and remote sensing software to predict future ULCs in the CMA. The entire modeling procedure involved the following processes: (1) model calibration; (2) simulation; and (3) validation. Model calibration (1) involves the modeling of a transition potential map (i.e., transition from non-built to built); simulation (2) involves the prediction of the quantities of ULCs (i.e., changes from non-built to built from 2001 to 2014, 2030, and 2050); and validation (3) comprises the allocation of the predicted changes (i.e., using the transition potential map to spatially allocate the predicted quantities of ULCs). The details of these modeling processes can be found in the literature [20,49-51]. More specifically, we used the MLP NN algorithm to model the transition potential map with the following inputs: the land-use/cover maps of 1992 and 2001 and the five driver variables, namely distance to major roads, distance to schools, distance to growth nodes, distance to administrative centers, and distance to existing built-up areas (1992). Then, we used the CA-Markov model to: (a) predict the quantity of ULCs for 2014, 2030, and 2050, based on the 1992 and 2001 land-use/cover maps; and (b) spatially allocate the predicted quantities of ULCs by using the transition potential map, while running the model in an unconstrained manner. We simulated three land-use/cover maps; i.e., for 2014, 2030, and 2050.

For the model validation, we assessed both the accuracy of the transition potential map and the 2014 simulated land-use/cover map. We used the area under the curve (AUC) statistic of the receiver/relative operating characteristic (ROC) module. The module compared the transition potential map with the Boolean map of the observed ULC from 2001 to 2014. The AUC is a summary statistic with values ranging from 0 to 1 , where a value of 0.5 represents no skill, a value of 1 indicates 
perfect skill, and values between 0 and 0.5 represent the incorrect calibration of the model [20,52]. Our AUC value was 0.822 , indicating that the transition potential map had a "high skill" in predicting future ULCs.

For an assessment of the accuracy of the simulated 2014 land-use/cover map, we used the figure of merit (FoM; Equation (3)). A three-map comparison was done between the observed 2001 and 2014 land-use/cover maps, and the simulated 2014 land-use/cover map in order to calculate the following: hits $(\mathrm{H})$, observed change correctly predicted as change; misses $(\mathrm{M})$, observed change incorrectly predicted as persistence; and false alarms (F), observed persistence incorrectly predicted as change. Our validation showed a FoM of $15.06 \%$. In another study, a FoM of $8.36 \%$ was achieved for a landscape with change of $11.3 \%$ [53]. In a review, it was found that landscapes observing change of $\sim<10 \%$ had FoM of $<15 \%$ [54]. Hence, our FoM is acceptable considering that we had only $7.25 \%$ ULC relative to the whole landscape during the simulation/validation interval (2001-2014).

$$
\operatorname{FoM}(\%)=\left[\frac{\mathrm{H}}{\mathrm{H}+\mathrm{M}+\mathrm{F}}\right] \times 100
$$

\section{Results}

\subsection{Temporal Pattern of ULCS in the CMA}

Figure 2 shows the three classified land-use/cover maps for the CMA (1992, 2001, and 2014) and the detected ULCs (i.e., gains of built or changes from non-built to built). In 1992, the CMA's built-up land had an area of 11,165 ha, which increased to 19,393 ha in 2001, and to 35,876 ha in 2014. This shows that the CMA's built-up land has increased by approximately $221 \%$ in the past 22 years (1992-2014), at a rate of 1123 ha per year.
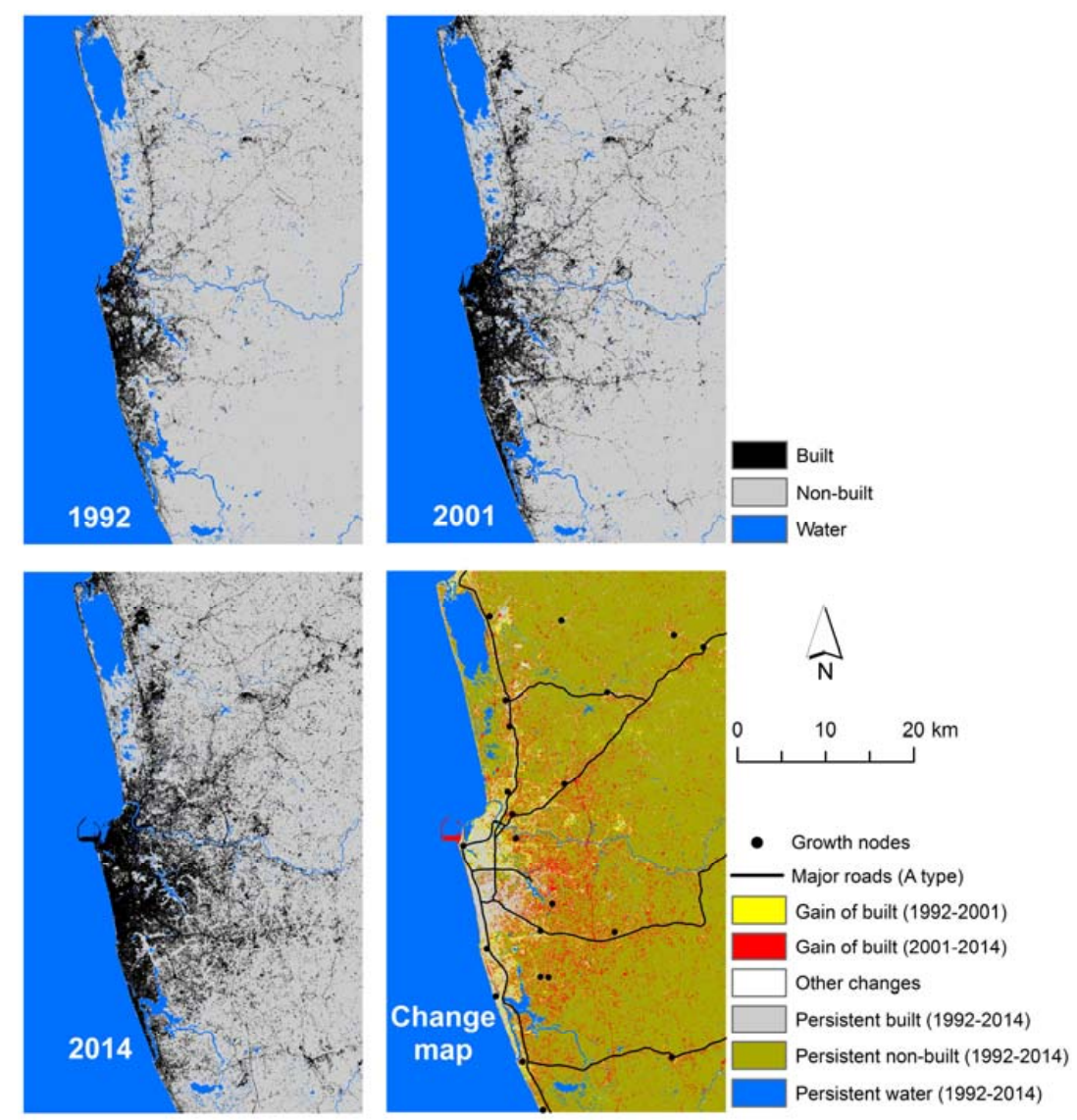

Figure 2. Land-use/cover maps of the CMA (1992, 2001, and 2014) and the detected ULCs. 
It is noteworthy that during the 1990s, ULC accounted for 3.5\% of the entire landscape, while during the 2000s, ULC accounted for 7.02\% (Figure 3). However, it should also be noted that the time duration during the 2000s is longer than that of the 1990s. Therefore, it is important to consider the ACI in the analysis. The ULC intensity analysis revealed that the ACI during the first time interval (1992-2001) was 0.39\%, while the second interval (2001-2014) had an ACI of $0.54 \%$ (Figure 3). With a UI of $0.48 \%$, the ACI during the 2000s is considered to be fast, while the ACI during the 1990 s is considered to be slow (Figure 3). It other words, the ULC intensity during the 2000s was faster than it was during the 1990s. Overall, these results show that ULC in the CMA was not stationary across the two time intervals. Some possible factors influencing this ULC non-stationarity in the CMA are discussed in Section 4.1.

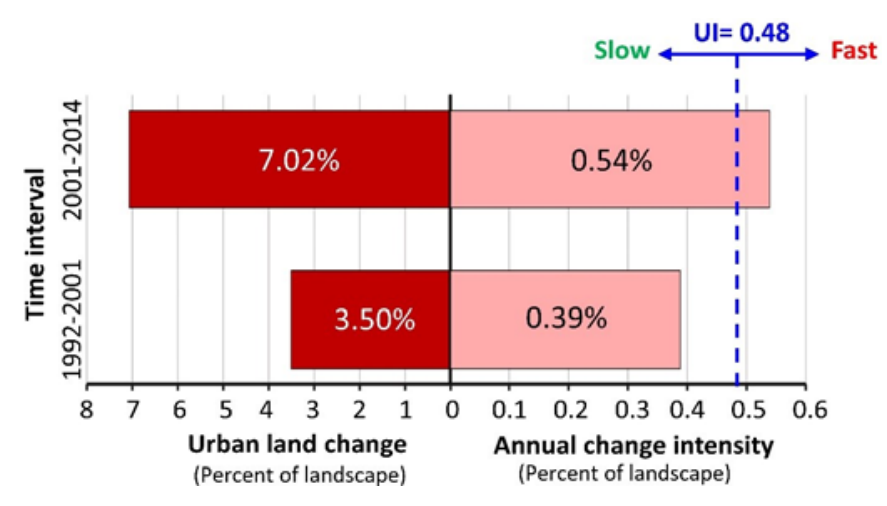

Figure 3. Intensity of ULCs in the CMA.

\subsection{Spatial Pattern of ULCS in the CMA}

Figure 4 shows the spatial distribution of ULCs along the gradients of the driver variables: (a) distance to major roads; (b) distance to schools; (c) distance to growth nodes; and (d) distance to administrative centers.

The results show that at $<1.5-\mathrm{km}$ distance along the gradients of all the driver variables, distance to major roads (1990s: 3.45\%; 2000s: 6.89\%) and distance to schools (1990s: 3.44\%; 2000s: 6.89\%) had much higher gains of built for both time intervals (the 1990s and 2000s). Distance to administrative centers (1990s: 2.71\%; 2000s: 3.71\%) and distance to growth nodes (1990s: $0.94 \%$; 2000s: $0.95 \%$ ) had much lower gains of built for both time intervals (Figure 4).

However, at a 1.5-3.0 km distance, the results show that distance to growth nodes (1990s: $1.14 \%$; 2000s: $1.49 \%$ ) and administrative centers (1990s: 0.52\%; 2000s: $0.52 \%$ ) had much higher gains of built during the 1990s and 2000s than distance to schools (1990s: $0.01 \% ; 2000 \mathrm{~s}: 0.07 \%$ ) and major roads (1990s: 0.00\%; 2000s: 0.08\%; Figure 4).

At distances $>3.0 \mathrm{~km}$, the results show that distance to growth nodes (1990s: $1.36 \% ; 2000 \mathrm{~s}: 3.80 \%$ ) and administrative centers (1990s: $0.22 \%$; 2000s: $0.93 \%$ ) also had much higher gains of built during the 1990s and 2000s than distance to schools (1990s: 0.00\%; 2000s: 0.01\%) and major roads (1990s: 0.00\%; 2000s: 0.00\%; Figure 4).

Overall, these results show that at closer distances $(<1.5 \mathrm{~km})$, the distance to major roads and schools were relatively more influential with regard to ULCs across the two time intervals. At further distances $(\geq 1.5 \mathrm{~km})$, however, the distances to growth nodes and administrative centers were relatively more influential. This pattern could be due to the limited availability of space for urban development near the growth nodes and administrative centers, as most of the area was built during the early 1990s, unlike the areas in close proximity to major roads and schools. 

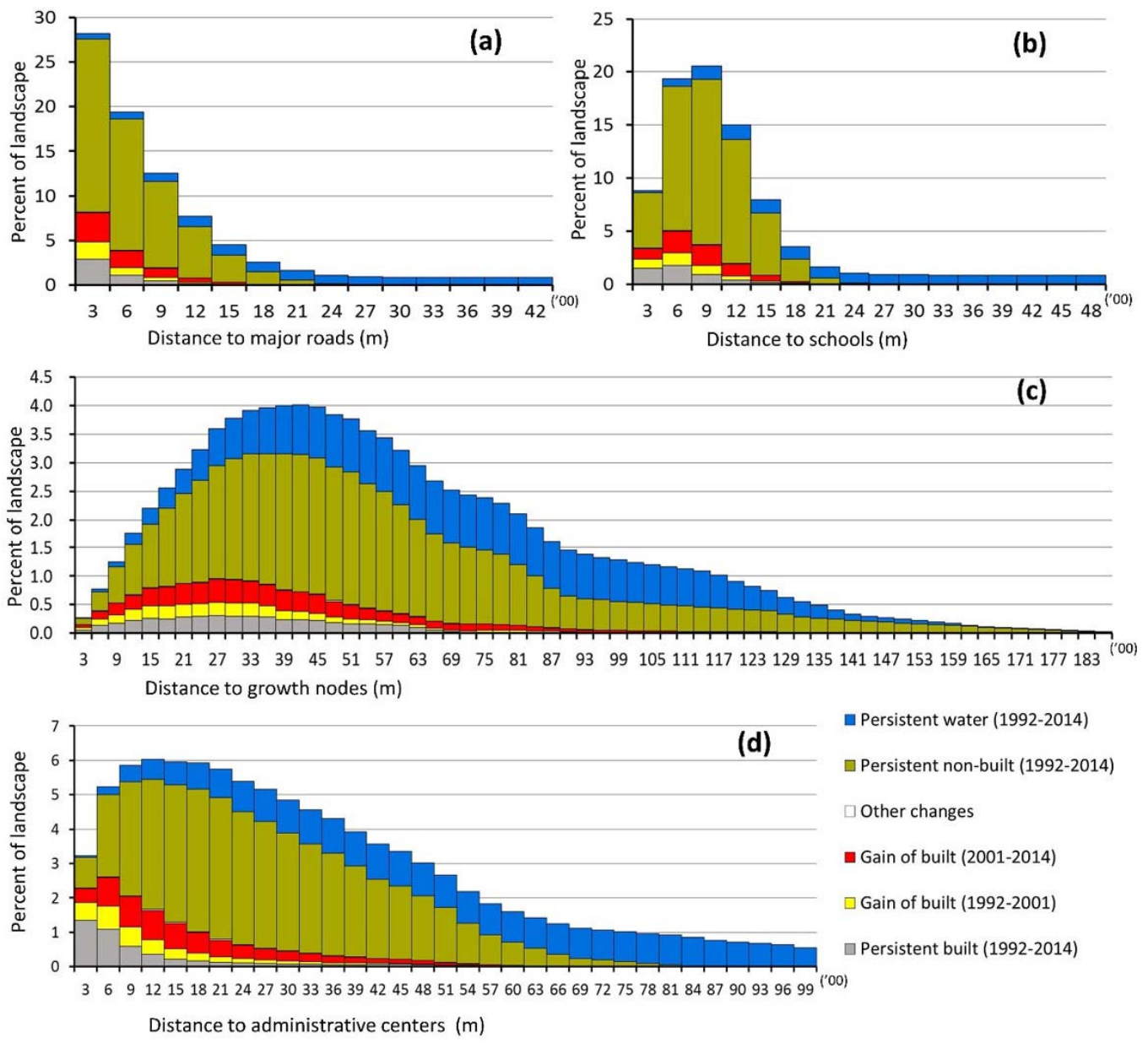

Figure 4. Observed ULCs along the gradients of the driver variables: (a) distance to major roads; (b) distance to schools; (c) distance to growth nodes; and (d) distance to administrative centers.

\subsection{Landscape Fragmentation and Connectivity in the $C M A$}

Accordingly, a decrease in the value of CONTAG indicates an increase in the level of fragmentation, while an increase in its value indicates an increase in the degree of clumpiness of the patches $[20,48]$. For the LSI, an increase in its value indicates an increase in the degree of landscape disaggregation or dispersion and in the overall complexity of the landscape, while an increase in the value of the SHDI indicates an increase in patch richness and/or the proportional distribution of an area among land-use/cover classes becoming more even [20,47,48]. Our results show that from 1992 to 2014, the value of CONTAG has decreased, while the values of LSI and SHDI have increased. This indicates that the landscape of the CMA has become more fragmented and dispersed; its patch richness has also increased (Figure 5a).

At the class level (built class), the results show that the values of PLAND, PD, AREA_MN, and Frac_AM have increased from 1992 to 2014, whereas the value of ENN_MN has decreased (Figure $5 b$ ). The increase in the values of PLAND and PD indicates that the CMA's built-up lands have become more fragmented. The size and shape of the CMA's patches of built-up lands have also become larger and more complex, as indicated by the increase in the values of AREA_MN and Frac_MN, respectively. The decrease in the value of ENN_MN was due to the increase in the size of built-up patches (i.e., AREA_MN) and the development of new built-up patches near or in between existing built-patches (i.e., $\mathrm{PD}$ ). 
(a)
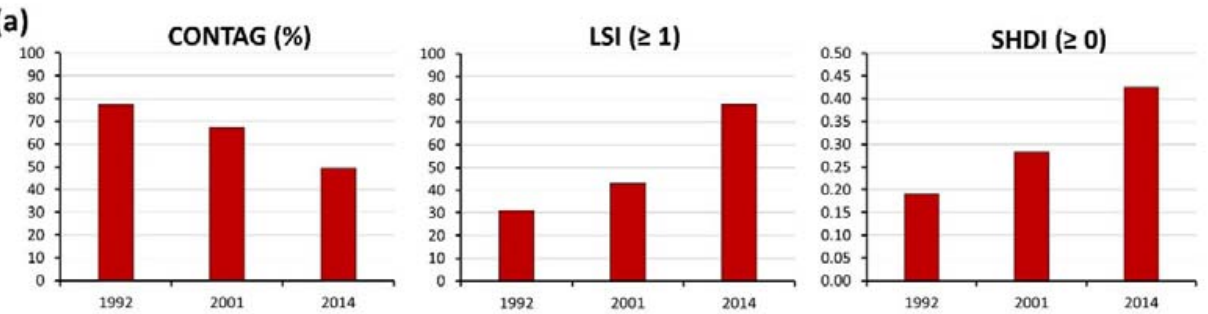

(b)
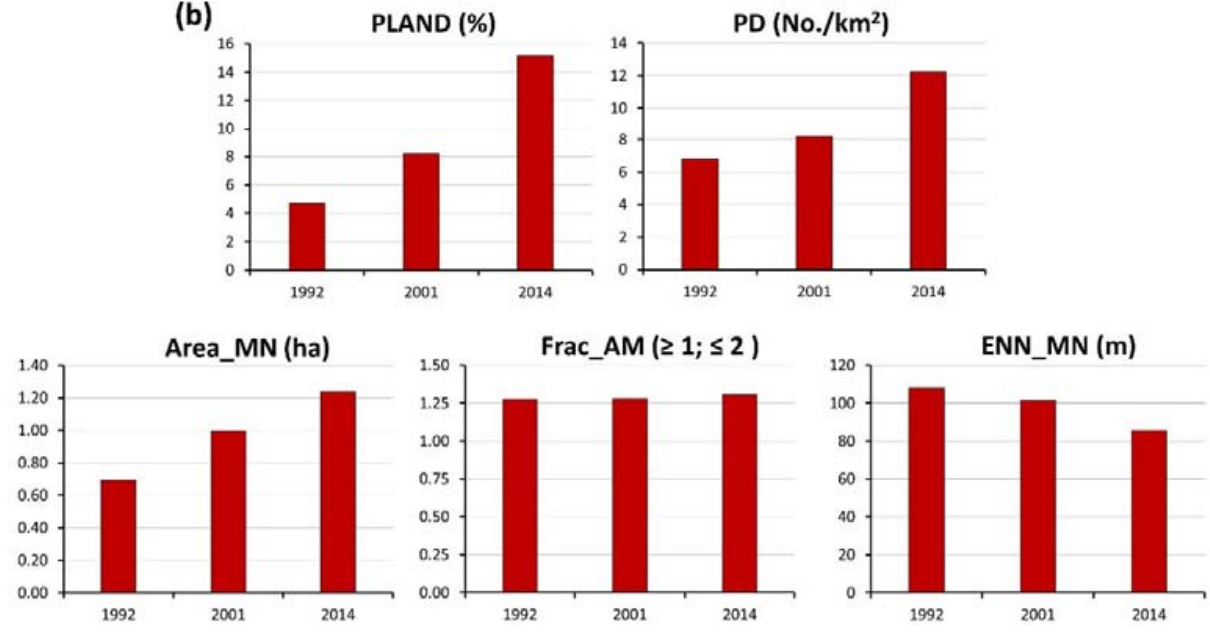

Figure 5. Spatial metrics at the (a) landscape level; and (b) class level (built class). Note: CONTAG, contagion index; LSI, landscape shape index; SHDI, Shannon's diversity index; PLANP, percentage of landscape; PD, path density; Area_MN, mean patch size; Frac_AM, area-weighted mean patch fractal dimension; and ENN_MN, mean Euclidean nearest neighbor distance.

\subsection{Predicted Future ULCs in the CMA}

Our modeling predicts built-up in 2030 and 2050 to be 42,500 ha and 56,000 ha, respectively. It can be observed that the predicted quantities of built for 2014, 2030, and 2050 depict a linear pattern due to the Markov Chain algorithm used, extending from the levels of development in 1992 and 2001 (Figure 6). However, the observed trend of ULCs in the CMA across the 1992-2014 period is non-linear (Figure 6). This non-linear trend of ULCs in the CMA is also explained in the context of ULC intensity in Section 3.1; i.e., the intensity of ULCs during the 1990s (1992-2001) was slower than during the 2000s (2001-2014). We explained in Section 2.6 that we used the 1992 and 2001 land-use/cover data to predict the quantity of ULCs from 2001 to 2014 as part of the model calibration process. This is the reason for the under-prediction of the quantity of built in 2014.

Uncertainty is common in modeling [55]. The uncertainties associated with land change modeling can come from three sources: the data, the model, and future land change processes [56]. First, data by nature are prone to many types of uncertainty, so a model is likely to use some erroneous information. In this study, in order to reduce the potential error that might be associated with our land-use/cover data, we carefully checked the accuracy of our classified land-use/cover maps. Secondly, land change models are constrained by several uncertainties, including those associated with prediction of the quantity of change and the spatial allocation of such change. In this study, we validated our modeling results by assessing the "skill" of our transition potential map and the accuracy of the simulation result. The validation revealed that our transition potential map has a high "skill" to predict future ULCs. Our simulation also had a higher FoM than those previously reported in the literature (see Section 2.6). Third, the non-stationary nature of land-use/cover changes creates uncertainties in the prediction of future changes [57]. The land change intensity analysis we performed in this study revealed that ULCs in the CMA were non-stationary. The Markov Chain algorithm we used in this study could not 
address the uncertainty due to the non-stationarity of the ULCs. In future studies, non-linear models should be explored. We acknowledge the limitation of our modeling results regarding "quantity". Nevertheless, our results still give an idea of the potential future ULC patterns in the CMA, as well as the spatial factors driving such patterns.

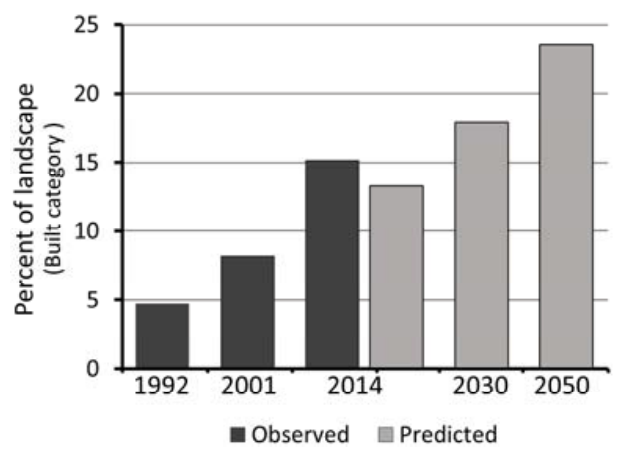

Figure 6. Observed and predicted quantities of built in the CMA.

Figure 7 shows the predicted 2030 and 2050 land-use/cover maps of the CMA, including the detected ULCs relative to the observed 2014 land-use/cover map. It is clearly visible on the maps how major roads and growth nodes will have great influence on the spatial pattern of future built-up expansions. The predictions also show that the northern and northeastern parts of the CMA will experience great landscape changes in the future. Built-up lands along the coast and in the central area will also become denser due to the infill development (Figure 7).
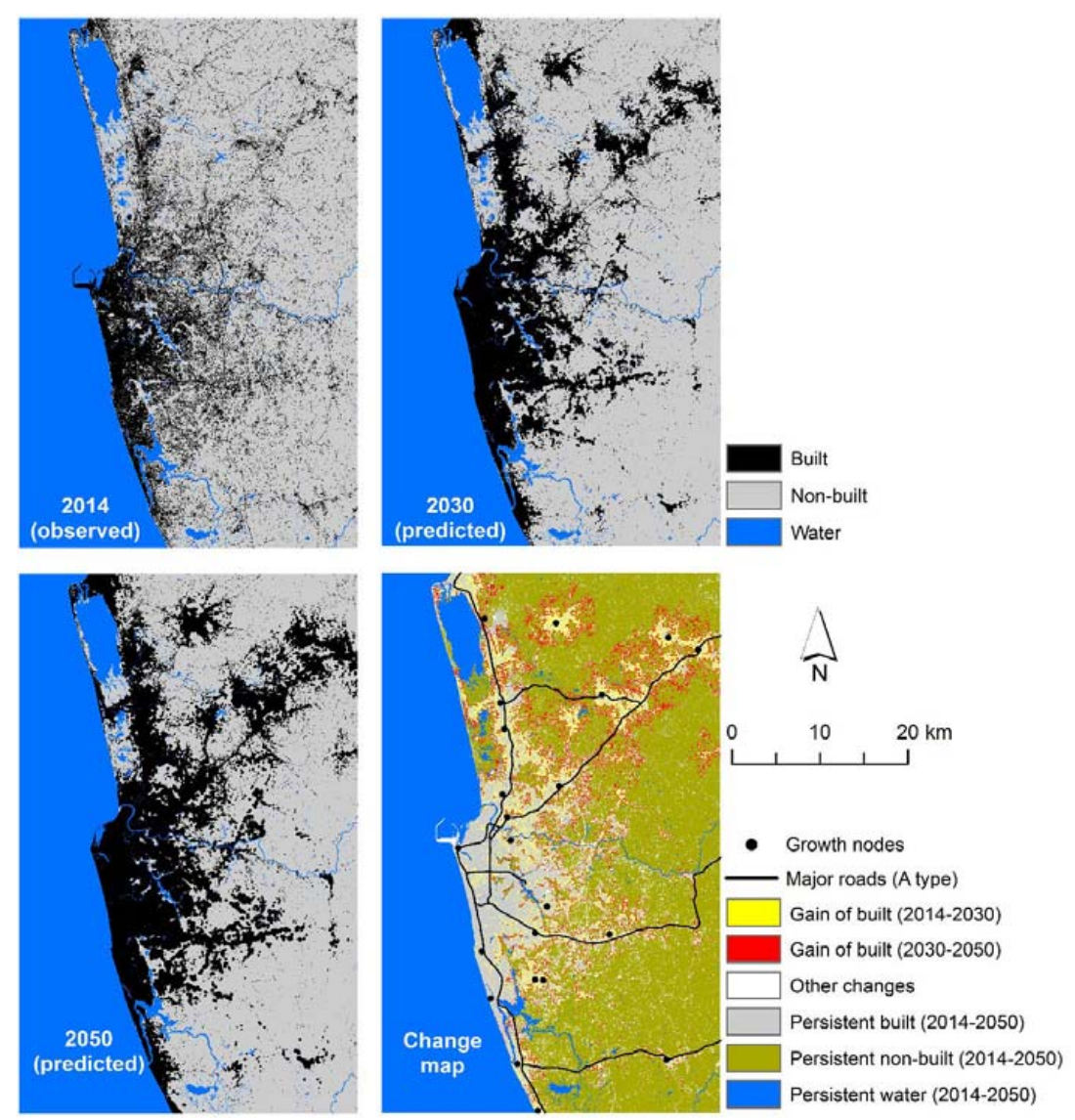

Figure 7. Observed (2014) and predicted (2030 and 2050) land-use/cover maps of CMA and the detected ULCs. 


\section{Discussion}

\subsection{Urban Growth of CMA and Other Major Cities in South Asia}

In general, urban growth in developing countries is influenced by population growth due to birth and in-migration [58]. However, among countries in the South Asian region, Sri Lanka (1.1\%) has a lower annual urban population growth rate when compared with those of Bangladesh $(3.4 \%)$, Nepal (3.2\%), Pakistan (3.3\%), and India (2.4\%) [59]. The CMA also has a slower annual population growth rate (APGR) and annual ULC rate when compared with those of other rapidly growing metropolitan areas in the South Asian region (Table 2). The slower APGR of the CMA is mainly caused by Sri Lanka's low annual population growth rate (0.7\%) [39], low levels of migration to the CMA in relation to the country's small size which allows people to reach urban areas within a reasonable time, the agricultural economic dominance, and the promotion of urban decentralization policies (until the 1990s) by the government [60].

Table 2. Built-up and population growth in selected South Asian metropolitan areas.

\begin{tabular}{cccc}
\hline Metropolitan Area & Years & $\begin{array}{c}\text { Annual ULC Rate } \\
\text { (\% of Landscape) }\end{array}$ & APGR (\%) \\
\hline Dhaka (Bangladesh) [61,62] & $1999-2005$ & 2.43 & 4.08 \\
Mumbai (India) [63,64] & $1991-2011$ & 0.94 & 2.15 \\
Hyderabad (India) [65] & $1971-2005$ & 0.58 & 2.96 \\
Kathmandu (Nepal) [66] & $1978-2000$ & 0.55 & 4.10 \\
Colombo (Sri Lanka) & $1992-2014$ & 0.47 & 0.41 \\
\hline
\end{tabular}

Note: The annual ULC rate as a percentage of landscape is calculated as: $\frac{\left[\left(\mathrm{BU}_{\mathrm{TI} 2}-\mathrm{BU}_{\mathrm{TI} 1}\right) / \mathrm{TE}\right]}{\mathrm{LA}} \times 100$ (BU is built-up area and all other notations are the same as in Section 2.3). The annual population growth rate (APGR) is calculated as: $\operatorname{APGR}(\%)=\left(\sqrt[n]{P_{\mathrm{t} 2} / P_{\mathrm{t} 1}}-1\right) \times 100$, where $\mathrm{P}$ is the population for a particular year, e.g., 1978 or 2000; and $\mathrm{n}$ is the time interval in years between two census dates, e.g., 2000-1978. Data for calculating the annual ULC rate and APGR were collected from published literature and World Urbanization Prospects: The 2014 Revision [5] (population was considered from records closest to the years of annual ULC rate).

* Statistics for Colombo were based on this study.

These statistics also revealed that the influence of population growth on urban built-up area expansion is weaker in the CMA when compared with the other metropolitan areas in South Asia. For instance, in other studies in South Asian metropolitan areas, it has been shown that population growth driven by the rural-urban migration as the major factor of urban growth, including urban built-up expansion $[62,65,66]$. However, due to the CMA being the only metropolitan area in Sri Lanka, industrial and commercial centers are concentrated in the CMA and they are growing rapidly with various urban development projects (i.e., port city project and beautification project). Moreover, with its central location in the region and it being one of the important nodes in the proposed "new silk road economic belt" [67], the CMA recently attracted large amounts of foreign direct investment (FDI). The FDI net inflow as a percentage of GDP of the country was $0.28 \%$ in 1990, 1.09\% in 2001, and $1.46 \%$ in 2011 [68]. Most of these foreign investments are industries, which were established in export processing zones (EPZs), such as in Katunayake, Biyagama, and Horana, which are located in the CMA. As a result, $80 \%$ of Sri Lanka's industries today are located in the CMA [12]. Moreover, the location of the administrative capital city, Sir Jawardhanapura Kotte, in the CMA has attracted most of the national government's administrative headquarters and several government institutions into the CMA. These factors, together with population growth, are among the underlying factors driving the rapid ULCs in the CMA.

\subsection{Stages of Urban Growth}

Our results show that ULCs in the CMA were more rapid and intense during the 2000s than during the 1990s. This non-stationarity of ULCs in the CMA is associated with population growth and economic growth. 
Census data show that the population growth rate in the CMA was higher during the 2000s than it was during the 1990s (Figure 8a). The higher population growth rate during the 2000s was influenced by rural-to-urban migration, just as in many other South Asian countries. After the mid-2000s, the decrease in the productivity of agriculture in dry areas of the country prompted the government to push rural-to-urban migration as a poverty-reducing initiative [69]. Employment in urban industrialized areas was seen as providing better living conditions for struggling farmers. This policy change motivated a generation of young migrants to settle in the CMA. As of 2012, 641,922 people entered Colombo alone, accounting for $16.2 \%$ of the country's total in-migration [39]. These migration statistics are low when compared with those of other dominant South Asian metropolitan areas, but these are the highest in the country.

In the 1990s, Sri Lanka's economy faced several challenges due to the Janatha Vimukthi Peramuna (JVP) insurrections (1987-1989) and a civil war (1983-2009). The combined influence of these two political movements weakened economic development in general and urbanization in particular [70]. However, after the end of the JVP insurrections in 1989 and the civil war in 2009, development in Colombo accelerated. Specifically after 2009, post-war policies attracted substantial foreign capital to Sri Lanka as a whole, and development projects in Colombo made it the country's industrial capital [71], an important factor driving the the rapid urban growth of the CMA in recent years. Furthermore, the slow urban growth of the CMA during the 1990s was due to the country's urban development policy at that time. In the 1980s and 1990s, government policy was focused more on the promotion of urban decentralization into north-central and eastern Sri Lanka, rather than on the development of Colombo and its suburbs [60]. This policy slowed down the growth of the CMA. However, from the 2000s up to the present, Colombo has developed to become the apex of Sri Lanka's urban system, providing the highest level of urban functions and services, which also contributed to the much improved GDP per capita in the country as a whole (Figure $8 b$ ).
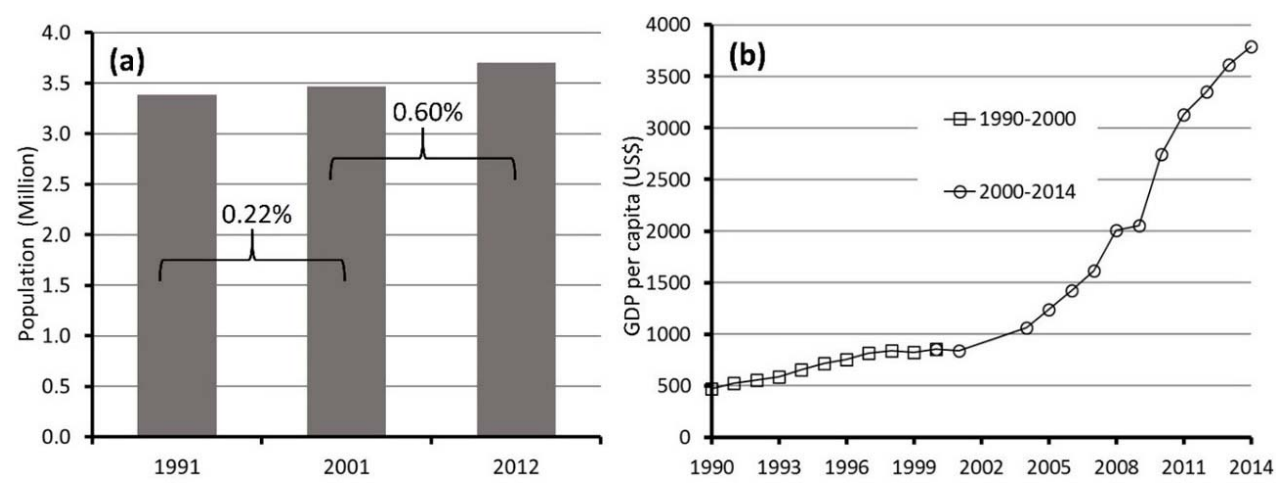

Figure 8. (a) APGR of the CMA (Data Source: Census data [36-39]); and (b) the GDP of Sri Lanka for various years [72]. Due to the lack of multi-temporal GDP data for the CMA, we used countrywide data as a proxy indicator. The CMA accounts for about 50\% of Sri Lanka's [9]. Note: GDP is in current US dollars.

\subsection{Spatial Patterns of ULCs and Their Implications}

Urban expansion along transport corridors (ribbon-type urban development) is a widespread form in many cities, including Beijing, Tokyo, Shanghai, and Shenzhen [73]. Our gradient analysis revealed that $75 \%$ (during the 1990s) and $82 \%$ (during the 2000s) of the total ULCs along the whole gradient of the distance to major roads occurred in close proximity (i.e., $<1.5 \mathrm{~km}$ from major roads). The much higher percentage during the later period (2000s) was due to the much higher ULC intensity during the said period (see also Sections 3.1 and 4.1; Figure 3). Nevertheless, these results confirm that the transport network has been influential in the spatial pattern of ULCs in the CMA. Compared with residential development, in the CMA commercial activities such as business and banking are more associated with this ribbon-type urban development. 
The spatial metrics analysis revealed that the CMA's built-up lands have become more fragmented (Section 3.3; Figure 5). This is due not only to the development of more built-up patches along the transport corridors, but also due to the diffusion of newly developed patches from the existing built-up areas around schools, growth nodes, and administrative centers. The analysis also revealed, however, that existing built-up patches have become larger and the distance between built-up patches has reduced (Section 3.3). The increase in the size of built-up patches was due to the process of extension or expansion, while the decrease in the mean distances between built-up patches was due to the combined effect of diffusion, expansion, and the development of new patches near or in between patches, which is also a type of infill urban development. In general, these results show evidence to support the diffusion-coalescence urban growth theory [28,74,75]: "Diffusion is a process in which new urban areas are dispersed from the origin point or 'seed' location, while coalescence is the union of individual urban patches, or the growing together of the individual urban patches into one form or group" [1]. Based on the results, we can say that the CMA is still in the early stages of this oscillating process; i.e., it is experiencing more diffusion and less coalescence. As a metropolitan area, the CMA is still young, with its urban development recovery having just started after the end of the civil war in 2009.

The landscape fragmentation and dispersed growth of the CMA may be caused by several factors. On the one hand, there are no major physical constraints, such as high elevation and steep slopes, in the land side of the CMA, which encourages landscape fragmentation and dispersed growth. On the other hand, a significant extension of road networks has been observed in the CMA during past two decades. This road development reduced the travel time from the suburbs to central areas or the business district (CBD) and has created land fragmentation. Consequently, people moved into the suburbs, influencing landscape fragmentation and dispersed urban growth. More specifically, the non-built-up lands in close proximity to the roads were gradually converted into built-up lands. The government industrialization strategy promoting the EPZs in the CMA generally enhanced population pressure and, in particular, influenced landscape fragmentation in the area. The influence of EPZs, represented by the growth nodes, on the urban growth of the CMA can be understood through the gradient analysis results. Moreover, the increase in the residential and commercial utility value of lands in the CMA leads to the proliferation of real estate agents participating in the land market and to the increased fragmentation of non-built-up lands, including agricultural and uncultivated lands in the past two decades [60].

The coalescence of built-up patches was mainly observed in the CBD and other highly urbanized areas such as the coastal area (Figure 2). The urban planning initiatives introduced in the CBD are one major factor that drives the coalescence of built-up patches. Under these urban planning initiatives, new road networks and functional zones (e.g., the administrative zone in Jayawardhanapura and paved walkable areas) were introduced to the central area of the CMA, resulting in the coalescence of built-up patches with infill development. Moreover, the proliferation of commercial function-based developments in the central area and tourism function-based development-e.g., hotels and parks-along the coastal area has promoted infill development. However, there are also infill developments in the CMA due to unplanned expansions of settlements in the CBD and in the coastal area.

The process of continuous diffusion and expansion can result in sprawl development, while the process of coalescence can result in an infilling growth pattern $[1,20]$. The infilling growth pattern has some potential advantages, including the promotion of walkable neighborhoods, the use of existing infrastructures, and the prevention of the associated external costs of sprawl development $[1,76]$. However, it also has some potential disadvantages, including limited open space, increased traffic congestion and pollution, the potential loss of urban green spaces, and crowded services $[1,20,77]$.

As infill development has lessened the space in the CBD of CMA for further development, ribbon-type development has radiated from the CBD along the major transport corridors and the western coastal belt. This concentrated urban footprint in the western part of the CMA has preserved 
most of the natural and rural environment of the eastern part. At present, the influence of the growth nodes on the CMA is not yet obvious. These growth nodes can help avoid any further congestion of the CBD, while giving opportunities to other parts of the CMA to develop. However, not only can these growth nodes influence urban sprawl in the future, they can also lead to ethnic and economic separation, environmental degradation, the loss of agricultural land and wilderness, and erosion of a society's architectural heritage [78]. Separate studies focusing on the future implications of these growth nodes are needed.

\subsection{Present and Future Urban Development Challenges}

Currently, the increased urban concentration in the CMA has created several socioeconomic and environmental issues that stem from extensive urban poverty, recurrent flooding, slum growth, extensive alteration of wetland ecosystems, and mismanagement of limited resources. Most of these socioeconomic and environment-related issues are also found in other metropolitan regions in the various developing countries $[7,8,20,25,79]$. The World Bank (2004) indicated that the CMA is the urban area in which poverty is most prevalent, although it shows the highest level of economic dominance in the country [80]. On the other hand, this phenomenon has prompted an increase in informal settlements, such as slums, shanties, and low cost flats. Many of these settlements experience overcrowding and are highly vulnerable to natural disasters. In Colombo city alone, where $30 \%$ of the country's population resides, UN Habitat estimates the number of slum-dwellers to be 65,000 [14]. Currently, most of these low income dwellers are concentered in environmentally sensitive areas such as wetlands and coastal lagoon areas (i.e., Muthurajawela and Aththidiya) [15]. This situation certainly affects the sustainability of the CMA.

It seems that in the context of this study, ongoing urban growth, loss of non-urban land, and higher levels of land fragmentation with dispersed urban growth in the CMA have not been resolved by the urban policies. Due to landscape fragmentation, the sustainability of the ecosystem could be affected. Thus, encouraging new development in already altered land can be effective in terms of urban planning. Vertical urban space in the CMA is very limited except for in the CBD; the promotion of vertical development particularly focused on the urbanized areas may help to reduce the pressure on the sustainability of the ecosystem. The results reveal that the major roads are highly influential for the urban growth of the area. However, planning initiatives need to address this factor when the new urban planning strategies are introduced.

Our prediction results show that: (a) ongoing urban growth will expand, covering a large area and increasing land fragmentation; (b) the major transport corridors and growth nodes will have a great influence on the future spatial patterns of ULCs; and (c) the CMA's built-up lands will be clumpier and aggregated due to infill development (Section 3.4; Figure 7). In the context of this study, we identified the following three important points which should be considered in the CMA's landscape and urban development planning.

First, with regard to the CMA's landscape and urban development planning, planners should anticipate the quantity and spatial patterns of future built-up expansions (sprawl and infill). This is in order to at least minimize the potential impact of ULCs on agricultural, forest, and wetland areas, including the remaining urban green spaces in the central area. If this aspect of urban development is overlooked, it could impact not only agricultural productivity, but also the whole ecological balance of the region.

Second, ribbon-type development will further increase the difficulty of practicing urban development planning initiatives because Sri Lanka's UDA has no jurisdiction over administratively defined rural areas, even if these areas contain a high concentration of urban features. Therefore, this type of urban development also needs to be taken into account in the CMA's landscape and urban development planning.

Third, the CMA's landscape and urban development planning should also pay particular attention to the coastal area, which has been projected to experience more intense ULCs in the future. 
Coastal areas, such as the one in the western CMA, are prone to disasters (e.g., tsunamis and cyclones). Thus, in the CMA's landscape and urban development planning, appropriate disaster risk-management plans should also be considered.

\section{Conclusions}

This study has examined the spatiotemporal patterns of urban growth of the CMA-Sri Lanka's only metropolitan area and the country's main socioeconomic "powerhouse"-from 1992 to 2014 using remote sensing data and GIS techniques. The analysis revealed that ULC was faster during the 2000s (1268 ha per year) than in the 1990s (914 ha per year), coinciding with the trend of rapid population increase and economic growth. The results also revealed that most of the ULCs in both periods occurred in close proximity to roads and schools, while also showing some indications of landscape fragmentation and infill urban development patterns. The ULC modeling revealed that by 2030 and 2050, the CMA's built-up land would increase to 42,500 ha and 56,000 ha, respectively, and that growth nodes and transport corridors would be more likely to influence the future spatial pattern of built-up lands. These findings are important in the context of landscape and urban development planning for the CMA. Overall, this study provided valuable information on the landscape transformation of the CMA, including some important challenges facing its future sustainable urban development.

Acknowledgments: This study was supported by the Japan Society for the Promotion of Science (Doctoral Fellowship Grant: ID No. 15J00611, 2015-16; and Grant-in-Aid for Scientific Research B: No. 26284129, 2016-16, Representative: Shyamantha Subasinghe).

Author Contributions: The corresponding author, Shyamantha Subasinghe, proposed the topic and spearheaded the design, data processing and analysis, and writing of the manuscript. Ronald C. Estoque and Yuji Murayama helped in the design, research implementation and analysis, and writing of the manuscript.

Conflicts of Interest: The authors declare no conflicts of interest.

\section{Appendix A}

Table A1. Error matrix for the classified 1992 land use/cover map.

\begin{tabular}{cccccc}
\hline \multirow{2}{*}{ Classified Data } & \multicolumn{3}{c}{ Reference Data } & \multirow{2}{*}{ Total } & \multirow{2}{*}{ User's Accuracy } \\
\cline { 2 - 5 } & Built & Non-Built & Water & & \\
\hline Built & 272 & 16 & 12 & 300 & 90.67 \\
Non-built & 31 & 258 & 11 & 300 & 86.00 \\
Water & 7 & 25 & 268 & 300 & 89.33 \\
\hline Total & 310 & 299 & 291 & 900 \\
\hline Producer's accuracy (\%) & 87.74 & 86.29 & 92.10 \\
\hline \multicolumn{7}{c}{ Overall Accuracy $(\%)=86.66 \%}$.
\end{tabular}

Table A2. Error matrix for the classified 2001 land use/cover map.

\begin{tabular}{cccccc}
\hline \multirow{2}{*}{ Classified Data } & \multicolumn{3}{c}{ Reference Data } & \multirow{2}{*}{ Total } & User's Accuracy \\
\cline { 2 - 4 } & Built & Non-Built & Water & & \\
\hline Built & 279 & 7 & 14 & 300 & 93.00 \\
Non-built & 14 & 274 & 12 & 300 & 91.33 \\
Water & 17 & 23 & 260 & 300 & 86.67 \\
Total & 310 & 304 & 286 & 900 & \\
Producer's accuracy (\%) & 90.00 & 90.13 & 90.91 & & \\
\hline
\end{tabular}


Table A3. Error matrix for the classified 2014 land use/cover map.

\begin{tabular}{cccccc}
\hline \multirow{2}{*}{ Classified Data } & \multicolumn{3}{c}{ Reference data } & \multirow{2}{*}{ Total } & User's Accuracy \\
\cline { 2 - 4 } & Built & Non-Built & Water & & \\
\hline Built & 286 & 6 & 8 & 300 & 95.33 \\
Non-built & 6 & 282 & 12 & 300 & 94.00 \\
Water & 9 & 16 & 275 & 300 & 91.67 \\
Total & 301 & 304 & 295 & 900 & \\
Producer's accuracy (\%) & 95.02 & 92.76 & 93.22 & \\
\hline \multicolumn{5}{c}{ Overall Accuracy $(\%)=93.66 \%}$.
\end{tabular}

\section{References}

1. Estoque, R.C.; Murayama, Y. Intensity and spatial pattern of urban land changes in the megacities of Southeast Asia. Land Use Policy 2015, 48, 213-222. [CrossRef]

2. Mertes, C.; Schneider, A.; Sulla-Menashe, D.; Tatem, A.; Tan, B. Detecting change in urban areas at continental scales with MODIS data. Remote Sens. Environ. 2015, 158, 331-347. [CrossRef]

3. Luck, M.; Wu, J. A gradient analysis of urban landscape pattern: A case study from the Phoenix metropolitan region, Arizona, USA. Landsc. Ecol. 2002, 17, 327-339. [CrossRef]

4. Aguilera, F.; Valenzuela, L.M.; Botequilha-Leitão, A. Landscape metrics in the analysis of urban land use patterns: A case study in a Spanish metropolitan area. Landsc. Urban Plan. 2011, 99, 226-238. [CrossRef]

5. United Nations. World Urbanization Prospects: The 2014 Revision: Highlights; United Nations: New York, NY, USA, 2014.

6. Ellis, P.; Robert, M. Leveraging Urbanization in South Asia: Managing Spatial Transformation for Prosperity and Livability; The World Bank: Washington, DC, USA, 2016.

7. Cohen, B. Urbanization in developing countries: Current trends, future projections, and key challenges for sustainability. Technol. Soc. 2006, 28, 63-80. [CrossRef]

8. Dewan, A.M.; Yamaguchi, Y. Land use and land cover change in Greater Dhaka, Bangladesh: Using remote sensing to promote sustainable urbanization. Appl. Geogr. 2009, 29, 390-401. [CrossRef]

9. The World Bank. Colombo: The Heartbeat of Sri Lanka. 2013. Available online: http:/ /www.worldbank. org/en/news/feature/2013/03/21/colombo-heartbeat-sri-lanka (accessed on 30 June 2016).

10. Divigalpitiya, P.; Ohgai, A.; Tani, T.; Watanabe, K.; Gohnai, Y. Modeling land conversion in the Colombo Metropolitan Area using cellular automata. J. Asian Archit. Build. Eng. 2007, 6, 291-298. [CrossRef]

11. Senanayake, I.P.; Welivitiya, W.D.D.P.; Nadeeka, P.M. Urban green spaces analysis for development planning in Colombo, Sri Lanka, utilizing THEOS satellite imagery-A remote sensing and GIS approach. Urban For. Urban Green. 2013, 12, 307-314. [CrossRef]

12. Emmanuel, R. Thermal comfort implications of urbanization in a warm-humid city: The Colombo Metropolitan Region (CMR), Sri Lanka. Build. Environ. 2005, 40, 1591-1601. [CrossRef]

13. Japan International Cooperation Agency (JICA). Urban Transport System Development Project for Colombo Metropolitan Region and Suburbs: Final Report Summary 2014; JICA: Colombo, Sri Lanka, 2014.

14. UN-Habitat. Summary of City Case studies, Global Report on Human Settlement 2003; Earthscan Publication: London, UK, 2003.

15. Hettiarachchi, M.; Morrison, T.H.; Wickramsinghe, D.; Mapa, R.; de Alwis, A.; McAlpine, C.A. The eco-social transformation of urban wetlands: A case study of Colombo, Sri Lanka. Landsc. Urban Plan. 2014, 132, 55-68. [CrossRef]

16. Arsanjani, J.J.; Helbich, M.; de Noronha Vaz, E. Spatiotemporal simulation of urban growth patterns using agent-based modeling: The case of Tehran. Cities 2013, 32, 33-42. [CrossRef]

17. Gutman, G.; Janetos, A.C.; Justice, C.O.; Moran, E.F.; Mustard, J.F.; Rindfuss, R.R.; Skole, D.; Turner, B.L.; Cochrane, M.A. Land Change Science: Observing, Monitoring and Understanding Trajectories of Change on the Earth's Surface; Kluwer Academic: New York, NY, USA, 2004. 
18. Rindfuss, R.R.; Walsh, S.J.; Turner, B.L.; Fox, J.; Mishra, V. Developing a science of land change: Challenges and methodological issues. Proc. Natl. Acad. Sci. USA 2004, 101, 13976-13981. [CrossRef] [PubMed]

19. Turner, B.L.; Lambin, E.F.; Reenberg, A. The emergence of land change science for global environmental change and sustainability. Proc. Natl. Acad. Sci. USA 2007, 104, 20666-20671. [CrossRef] [PubMed]

20. Estoque, R.C.; Murayama, Y. Quantifying landscape pattern and ecosystem service value changes in four rapidly urbanizing hill stations of Southeast Asia. Landsc. Ecol. 2016, 31, 1-27. [CrossRef]

21. Bagan, H.; Yamagata, Y. Land-cover change analysis in 50 global cities by using a combination of Landsat data and analysis of grid cells. Environ. Res. Lett. 2014, 9, 1-13. [CrossRef]

22. Aldwaik, S.Z.; Pontius, R.G. Intensity analysis to unify measurements of size and stationarity of land changes by interval, category, and transition. Landsc. Urban Plan. 2012, 106, 103-114. [CrossRef]

23. Hersperger, A.M.; Gennaio, M.-P.; Verburg, P.H.; Bürgi, M. Linking land change with driving forces and actors: Four conceptual models. Ecol. Sco. 2010, 15, 1-17.

24. Long, H.; Tang, G.; Li, X.; Heilig, G.K. Socio-economic driving forces of land-use change in Kunshan, the Yangtze River Delta economic area of China. J. Environ. Manag. 2007, 83, 351-364. [CrossRef] [PubMed]

25. Estoque, R.C.; Murayama, Y. Examining the potential impact of land use/cover changes on the ecosystem services of Baguio city, the Philippines: A scenario-based analysis. Appl. Geogr. 2012, 35, 316-326. [CrossRef]

26. He, C.; Zhao, Y.; Tian, J.; Shi, P. Modeling the urban landscape dynamics in a megalopolitan cluster area by incorporating a gravitational field model with cellular automata. Landsc. Urban Plan. 2013, 113, 78-89. [CrossRef]

27. Estoque, R.C.; Murayama, Y.; Kamusoko, C.; Yamashita, A. Geospatial analysis of urban landscape pattern in three major cities of Southeast Asia. Tsukuba Geoenviron. Sci. 2014, 10, 3-10.

28. Wu, J.; Jenerette, G.D.; Buyantuyev, A.; Redman, C.L. Quantifying spatiotemporal patterns of urbanization: The case of the two fastest growing metropolitan regions in the United States. Ecol. Complex. 2011, 8, 1-8. [CrossRef]

29. Shannon, C.; Weaver, W. The Mathamatical Theory of Communication, 1st ed.; The University of Illinois Press: Urbana, IL, USA, 1964.

30. Mandelbrot, B.B. The Fractal Geometry of Nature, 1st ed.; Freeman: New York, NY, USA, 1989.

31. DiBari, J.N. Evaluation of five landscape-level metrics for measuring the effects of urbanization on landscape structure: The case of Tucson, Arizona, USA. Landsc. Urban Plan. 2007, 79, 308-313. [CrossRef]

32. Plexida, S.G.; Sfougaris, A.I.; Ispikoudis, I.P.; Papanastasis, V.P. Selecting landscape metrics as indicators of spatial heterogeneity-A comparison among Greek landscapes. Int. J. Appl. Earth Obs. Geoinf. 2014, 26, 26-35. [CrossRef]

33. Fan, C.; Myint, S. A comparison of spatial autocorrelation indices and landscape metrics in measuring urban landscape fragmentation. Landsc. Urban Plan. 2014, 121, 117-128. [CrossRef]

34. Arsanjani, J.J.; Helbich, M.; Kainz, W.; Boloorani, A.D. Integration of logistic regression, Markov chain and cellular automata models to simulate urban expansion. Int. J. Appl. Earth Obs. Geoinf. 2012, 21, 265-275. [CrossRef]

35. Horen, B.V. City profile: Columbo. Cities 2002, 19, 217-227. [CrossRef]

36. Department of Census and Statistics. Sri Lanka Census of Population and Housing 1981; Department of Census and Statistics: Colombo, Sri Lanka, 1984.

37. Department of Census and Statistics. Vital Statistics; Department of Census and Statistics: Colombo, Sri Lanka, 1991.

38. Department of Census and Statistics. Preliminary Evaluation of Age-Sex Data of Census of Population and Housing 2001: Colombo; Department of Census and Statistics: Colombo, Sri Lanka, 2001.

39. Department of Census and Statistics. Census of Population and Housing 2012. Key Finding: Colombo; Department of Census and Statistics: Colombo, Sri Lanka, 2012.

40. Thapa, R.B.; Murayama, Y. Urban mapping, accuracy, \& image classification: A comparison of multiple approaches in Tsukuba City, Japan. Appl. Geogr. 2009, 29, 135-144.

41. Rozenstein, O.; Karnieli, A. Comparison of methods for land-use classification incorporating remote sensing and GIS inputs. Appl. Geogr. 2011, 31, 533-544. [CrossRef]

42. Estoque, R.C.; Murayama, Y. Landscape pattern and ecosystem service value changes: Implications for environmental sustainability planning for the rapidly urbanizing summer capital of the Philippines. Landsc. Urban Plan. 2013, 116, 60-72. [CrossRef] 
43. McDonnell, M.J.; Hahs, A.K. The use of gradient analysis studies in advancing our understanding of the ecology of urbanizing landscapes: Current status and future directions. Landsc. Ecol. 2008, 23, 1143-1155. [CrossRef]

44. Sinha, P.; Kumar, L.; Reid, N. Rank-based methods for selection of landscape metrics for land cover pattern change detection. Remote Sens. 2016, 8, 1-19. [CrossRef]

45. Civco, D.L.; Hurd, J.D.; Wilson, E.H.; Arnold, C.L.; Prisloe, M.P. Quantifying and describing urbanizing landscapes in the northeast United States. Photogramm. Eng. Remote Sens. 2002, 68, 1083-1090.

46. Dewan, A.M.; Yamaguchi, Y.; Rahman, Z. Dynamics of land use/cover changes and the analysis of landscape fragmentation in Dhaka Metropolitan. GeoJournal 2012, 77, 315-330. [CrossRef]

47. Li, C.; Li, J.; Wu, J. Quantifying the speed, growth modes, and landscape pattern changes of urbanization: A hierarchical patch dynamics approach. Landsc. Ecol. 2013, 28, 1875-1888. [CrossRef]

48. McGarigal, K.; Cushman, S.A.; Ene, E. FRAGSTATS v4: Spatial Pattern Analysis Program for Categorical and Continuous Maps. Available online: http://www.umass.edu/landeco/research/fragstats/fragstats.html (accessed on 30 June 2016).

49. Verburg, P.H.; Kok, K.; Pontius, R.G.; Veldkamp, A. Modeling land-use and land-cover change. In Land-Use and Land-Cover Change: Local Processes and Global Impacts; Lambin, E.F., Geist, H.J., Eds.; Springer: Berlin, Germany, 2010; pp. 117-135.

50. Mas, J.F.; Kolb, M.; Paegelow, M.; Camacho Olmedo, M.T.; Houet, T. Inductive pattern-based land use/cover change models: A comparison of four software packages. Environ. Model. Softw. 2014, 51, 94-111. [CrossRef]

51. Camacho Olmedo, M.T.; Pontius, R.G.; Paegelow, M.; Mas, J.F. Comparison of simulation models in terms of quantity and allocation of land change. Environ. Model. Softw. 2015, 69, 214-221. [CrossRef]

52. Eastman, J.R.; Solorzan, L.A.; van Fosse, M.E. Transition potential modeling for land-cover change. In GIS, Spatial Analysis and Modeling; Maguire, D.J., Batty, M., Goodchild, M.F., Eds.; ESRI Press: Redlands, AB, Canada, 2005; pp. 357-385.

53. Sloan, S.; Pelletier, J. How accurately may we project tropical forest-cover change? A validation of a forward-looking baseline for REDD. Glob. Environ. Chang. 2012, 22, 440-453. [CrossRef]

54. Pontius, R.G.; Boersma, W.; Castella, J.C.; Clarke, K.; Nijs, T.; Dietzel, C.; Duan, Z.; Fotsing, E.; Goldstein, N.; Kok, K.; et al. Comparing the input, output, and validation maps for several models of land change. Ann. Reg. Sci. 2008, 42, 11-37. [CrossRef]

55. Tayyebi, A.H.; Tayyebi, A.; Khanna, N. Assessing uncertainty dimensions in land-use change models: Using swap and multiplicative error models for injecting attribute and positional errors in spatial data. Int. J. Remote Sens. 2014, 35, 149-170. [CrossRef]

56. Pontius, R.G.; Neeti, N. Uncertainty in the difference between maps of future land change scenarios. Sustain. Sci. 2010, 5, 39-50. [CrossRef]

57. Estoque, R.C.; Murayama, Y. A geospatial approach for detecting and characterizing non-stationarity of land change patterns and its potential effect on modeling accuracy. GISci. Remote Sens. 2014, 51, $239-252$. [CrossRef]

58. Taubenböck, H.; Esch, T.; Felbier, A.; Wiesner, M.; Roth, A.; Dech, S. Monitoring urbanization in mega cities from space. Remote Sens. Environ. 2012, 117, 162-176. [CrossRef]

59. The World Development Indicators: Urban Population Growth (Annual \%). Available online: http:/ / data.worldbank.org/indicator/SP.URB.GROW (accessed on 5 September 2016).

60. Groves, P.A. Urbanization and migration: Pattern and process. In Economic Development and Social Change in Sri Lanka:A Spatial and Policy Analysis, 1st ed.; Groves, P.A., Ed.; Manohar Publication: New Delhi, India, 1996; pp. 41-79.

61. Siddiqui, K.; Ahmed, J.; Siddique, K.; Huq, S.; Hossain, A.; Nazimud-Doula, S.; Rezawana, N. Social Formation in Dhaka, 1985-2005: A Longitudinal Study of Society in a Third World Megacity; Routledge: London, UK, 2010.

62. Dewan, A.M.; Yamaguchi, Y. Using remote sensing and GIS to detect and monitor land use and land cover change in Dhaka Metropolitan of Bangladesh during 1960-2005. Environ. Monit. Assess. 2009, 150, 237-249. [CrossRef] [PubMed]

63. Chatterjee, R.; Rahman, A.; Tran, T.; Shaw, R. Food security in Asia. In Urban Disaster Resilience in Asia; Shaw, R., Rahman, A., Surjan, A., Parvin, G.A., Eds.; Elsevier: Oxford, UK, 2016.

64. Kamini, J.; Jayanthi, S.; Raghavswamy, V. Spatio-temporal analysis of land use in urban Mumbai-Using multi-sensor satellite data and GIS techniques. J. Indian Soc. Remote Sens. 2006, 34, 385-396. [CrossRef] 
65. Rahman, A.; Aggarwal, S.P.; Netzband, M.; Fazal, S. Monitoring urban sprawl using remote sensing and GIS techniques of a fast growing urban centre, India. IEEE J. Sel. Top. Appl. Earth Obs. Remote Sens. 2011, 4, $56-64$. [CrossRef]

66. Thapa, R.B.; Murayama, Y. Examining spatiotemporal urbanization patterns in Kathmandu Valley, Nepal: Remote sensing and spatial metrics approaches. Remote Sens. 2009, 1, 534-556. [CrossRef]

67. Zimmerman, T. The New Silk Roads: China, the U.S., and the Future of Central Asia; New York University: New York, NY, USA, 2015. Available online: http://cic.nyu.edu/sites/default/files/zimmerman_new_silk_ road_final_2.pdf (accessed on 5 September 2016).

68. The World Bank, World Development Indicators: Foreign Direct Investment, Net Inflows (\% of GDP). Available online: http:/ / data.worldbank.org/indicator/BX.KLT.DINV.WD.GD.ZS?locations=LK (accessed on 5 September 2016).

69. Hewavitharana, B. Poverty alleviation. In Economic Policy in Sri Lanka: Issues and Debates, 1st ed.; Kelagama, S., Ed.; Sage Publication: New Delhi, India, 2004; pp. 467-497.

70. Misra, R.P.; Tiwari, P.S. Colombo: The primate city of Sri Lanka. In Urbanization in South Asia: Focus on Mega Cities, 1st ed.; Misra, R.P., Ed.; Cambridge University Press: New Delhi, India, 2013; pp. 421-445.

71. Hogg, C.L. Sri Lanka: Prospects for Reform and Reconciliation, Asia Programme Paper. Available online: https://www.chathamhouse.org/sites/files/chathamhouse/1011pp_srilanka_0.pdf (accessed on 28 June 2016).

72. The World Bank, World Development Indicators: GDP (Current US\$). Available online: http:/ / data.worldbank.org/indicator/NY.GDP.MKTP.CD?locations=LK (accessed on 8 September 2016).

73. Wu, Y.; Li, S.; Yu, S. Monitoring urban expansion and its effects on land use and land cover changes in Guangzhou city, China. Environ. Monit. Assess. 2015, 188, 54. [CrossRef] [PubMed]

74. Dietzel, C.; Oguz, H.; Hemphill, J.J.; Clarke, K.C.; Gazulis, N. Diffusion and coalescence of the Houston Metropolitan Area: Evidence supporting a new urban theory. Environ. Plan. B Plan. Des. 2005, 32, 231-246. [CrossRef]

75. Liu, X.; Li, X.; Chen, Y.; Tan, Z.; Li, S.; Ai, B. A new landscape index for quantifying urban expansion using multi-temporal remotely sensed data. Landsc. Ecol. 2010, 25, 671-682. [CrossRef]

76. McConnell, V.; Wiley, K. Infill development: Perspectives and evidence from economics and planning. In The Oxford Handbook of Urban Economics and Planning; Brooks, N., Donaghy, K., Knaap, G., Eds.; Oxford University Press: New York, NY, USA, 2011; pp. 473-502.

77. Houck, M.C. In livable cities is preservation of the wild. In The Routledge Handbook of Urban Ecology; Douglas, I., Goode, D., Houck, M., Wang, R., Eds.; Routledge: London, UK, 2010; pp. 48-62.

78. Rahimi, A. A methodological approach to urban land-use change modeling using infill development pattern-A case study in Tabriz, Iran. Ecol. Process. 2016, 5, 1. [CrossRef]

79. Dewan, A.M.; Kabir, M.H.; Nahar, K.; Rahman, M.Z. Urbanization and environmental degradation in Dhaka metropolitan area of Bangladesh. Int. J. Environ. Sustain. Dev. 2012, 11, 118-147. [CrossRef]

80. The World Bank, Sri Lanka: Reshaping Economic Geography, Connecting People to Prosperity, 2004. Available online: http://www.worldbank.org/en/news/feature/2012/05/16/reshaping-economicgeography (accessed on 8 September 2016).

(C) 2016 by the authors; licensee MDPI, Basel, Switzerland. This article is an open access article distributed under the terms and conditions of the Creative Commons Attribution (CC-BY) license (http://creativecommons.org/licenses/by/4.0/). 